\title{
複数連結汽水湖の水温, 塩分の変動
}

\author{
Water Temperature and Salinity Variations \\ in Interconnected Saline Lakes
}

\author{
松本治彦 $*$. 合屋晏秀 $* *$. 李寅鉄 $* * *$ \\ ·羽田野袈裟義 $* * * *$. 斎藤隆 \\ By Haruhiko MATSUMOTO, Yasuhide GOHYA, In-Cheol LEE, \\ Kesayoshi HADANO and Takashi SAITO
}

\begin{abstract}
This paper discusses field observation and model results for temperature and salinity in Myojin-ike, a group of saline lake. Myojinike is itself composed of three smaller interconnected basins, the largest of which is connected to the sea of Japan. Water temperature and salinity observed $0.5 \mathrm{~m}$ and $3.0 \mathrm{~m}$ below water surface showed abrupt variations like a step function during November to December 1985. This phenomenon is investigated in relation to the water movement in the lake.
\end{abstract}

Keywords: saline lake, water temperature, salinity, abrupt variation

\section{1.はじめに}

内湾や通水路を通じて外海と結ばれている湖沼の多くでは，水の交換が抑えられるため，水質污 濁が深刻な問題となっている．著者らはこのような水域の一例として夏季を中心に近年しばしば赤 潮が発生している「明神池」（山口県萩市）をとり，水温と塩分の連続測定を数年来行ない, 潮位 変動に伴う池内の流動特性と水質変動を検討している. その結果, ある期間では表層と下層の塩分 が約 1 日周期で急激に変化することを見いだした。本研究ではこの現象の生じる機構を潮位変動や 各池間の流量変化から考察している.

2. 明神池の概要と観測方法

図- 1 に調査した明神池と観測点を示す。この池は大池, 中の池および奥の池の 3 つの小さな池

* 正会員 工博 宇部短大助教授 付属環境科学研究所（テ755 山口県宇部市文京町 5-40）

** 農博 宇部短大教授 付属環境科学研究所

*** 山口大学大学院博士後期課程 ( 7755 山口県宇部市常盤台)

$* * * *$. 正会員 工博 山口大学助教授 工学部社会建設工学科

$* * * * *$ 正会員 工博 山口大学教授 工学部社会建設工学科 
からなり，表面積はそれぞれ $8646 \mathrm{~m}^{2}, 1553 \mathrm{~m}^{2}$ および $321 \mathrm{~m}^{2}$ である. 大池は, 最大水深が $6 \mathrm{~m}$ 程度で, 外海とは暗渠で通じてい る. 中の池は最大水深が $1.5 \mathrm{~m}$ 程度の浅い皿状の池で, 大池とは 2 本の短い水路で結ばれている．奥の池は玄武岩の山地で，岩塊に取 り囲まれた平均水深 が1 $\mathrm{m}$ 程度の小鉢状の形態をした池である.

奥の池と中の池は長さ約 $30 \mathrm{~m}$ の細い水路で連なっている1). また, 図-1の大池等深図をみると測点付近ですり鉢状に急激に深くなっ ていることがわかる.

現地観測は1985年11月8日〜12月 5日（前期調查）および12月 14日～1986年1月 15日（後期調查）までの期間に，図-1に示した Stn. 1 の水面下 $0.5 \mathrm{~m}$ おび $3.0 \mathrm{~m}$ の位置にメモリ一塩分・水温計 （モデルCTー2000）を設置し，連続測定を行なった。測定間隔は 30分である。解析には以上のデータの他に同期間の萩検潮場（国

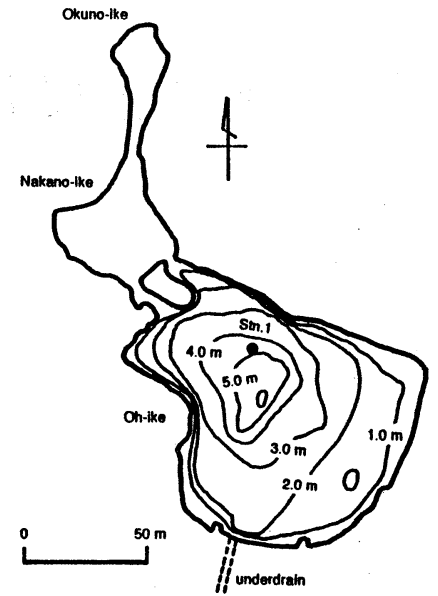

図 - 1 明神池と観測点 土地理院）の潮位記録を利用した。

\section{3 . 観測結果}

図- 2 に1985年11月8日〜12月5日までの 期間（前期）にStn. 1 の $0.5 \mathrm{~m}$ 層と $3.0 \mathrm{~m}$ 層で 測定した水温と塩分の時間変化を示す. 図3 に1985年12月14日～1986年1月15日ま での期間（後期）に上述と同様に測定した 結果を示す．また，図-4には水温・塩分の 観測期間に於ける萩検潮場の潮位記録を示 す. 以上の図より観測結果を前期と後期に 分けて述べる.

\section{1 前期調查}

水温をみると, 平均值は $0.5 \mathrm{~m}$ 層 (表層) が $17.3^{\circ} \mathrm{C} ， 3.0 \mathrm{~m}$ 層(下層) が17.8 ${ }^{\circ} \mathrm{C}$ で表層の方が下層よりも $0.5^{\circ} \mathrm{C}$ 低い。また観測を開始して6日 目までは両層の水温はほほ一致した 值を示し, 更にこの時期の水温は 21 ${ }^{\circ} \mathrm{C}$ 前後から $17^{\circ} \mathrm{C}$ 台へと急低下してい る。一方，11月14日より12月5日ま での観測期間では, 両層の水温には かなり差があり, 最大では $1{ }^{\circ} \mathrm{C}$ 以上 も表層の方が低くなっている，塩分 をみると, 平均值は表層で $29.12 \%$ ， 下層で $30.63 \%$ と下層の方が表層よ りも $1.51 \%$ 高い．表層に注目すると
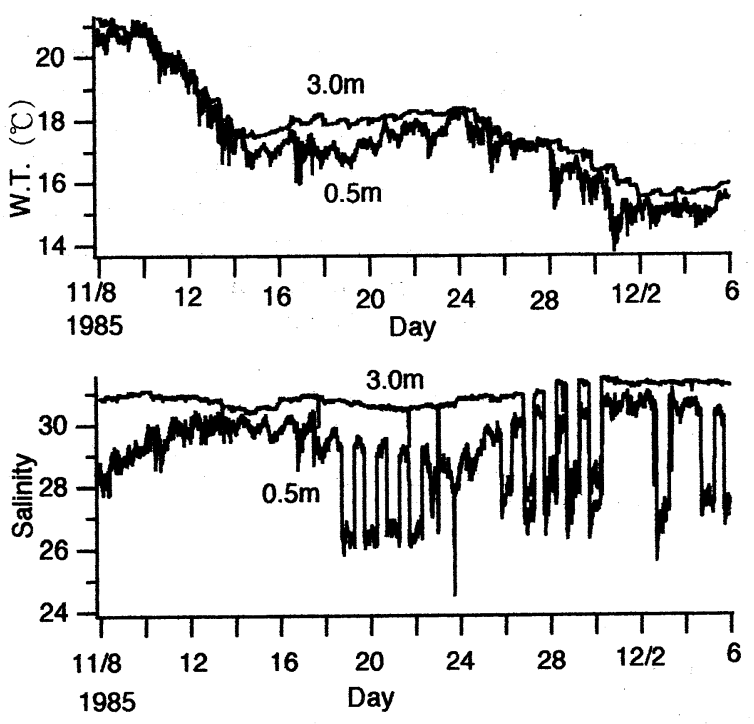

図 - 2 水温と塩分の時間変化（前期調査）
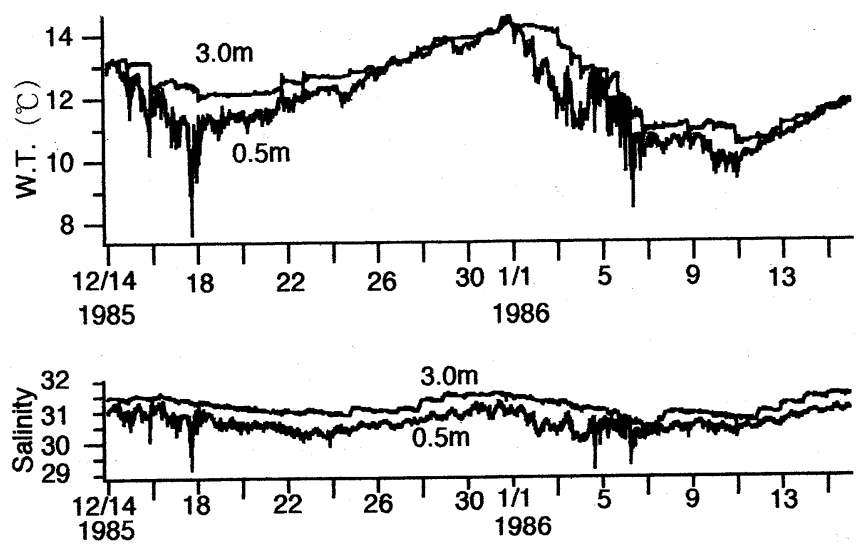

図 -3 水温と塩分の時間変化（後期調査） 
観測開始した11月8日には28\%台 であるが，11月11日には30\%前後 まで上昇し，その後は $30 \%$ を中心に した周期的な変動となっている. と ころが11月18日午後にはそれまで より約 $3 \%$ も急激に低下し，この状 態が13時間続いた後に，塩分は 29

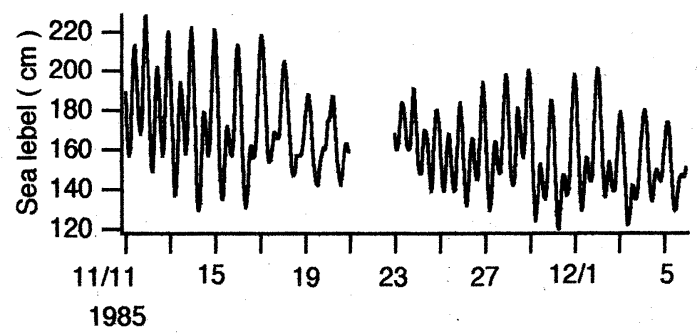
\%台に回復し，この状態が10時間続 いた後にふたたび急低下した。この 塩分の急変は11月18日から12月5日 にかけて起こっており，このうち 11 月18日から23日および26日から 30 日の期間で周期約 1 日の急変が継続 した.

次に下層の塩分をみると，11月8日

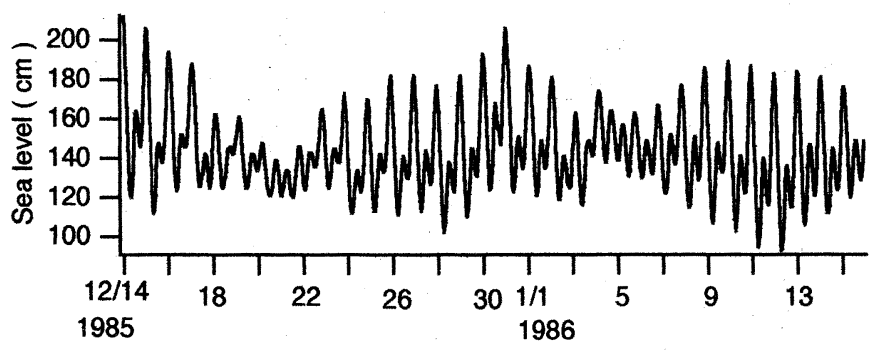

図 - 4 潮位の時間変化（萩検潮場）

より26日までの間，概ね30.5\%以上（平均で30．73\%）で変動の小さい安定した值を保っていた. なおこの期間， 3 度にわたって一時的にその直前の濃度より $1 \%$ から $4 \%$ 低下した箇所がみられる. ところが11月26日の夜から 30 日までの間, 表層と同様に約 1 日の周期で塩分が急変していた。特 に塩分が急激に低下している間，一時的に下層の塩分が表層の塩分よりも低い期間のあることが注 目される。

次に潮位変化についてみると, 塩分急変の起こる前の一週間の潮位（11月11日から17日までの 期間）は高高潮での潮位が $220 \mathrm{c} \mathrm{m}$ 近くと高い. 次に急変期（11月18日から12月5日）の潮位をみ ると, 表層のみ急変する時期（11月18日から25日）には, 高高潮でも $180 \mathrm{c} \mathrm{m}$ 台と低いが, 表層 と下層の塩分が急変する時期（11月26日から 30 日）には高高潮の潮位は $200 \mathrm{c} \mathrm{m}$ 前後と再び高く なっている．さらに観測期間の最後の方でみられた表層のみ急変する時期（12月 1 日から 5 日）に は高高潮の潮位は再び $180 \mathrm{~cm}$ 前後と低い. 以上のことから高高潮の潮位が塩分の急変と密接に関 連することがわかる.

\section{2 後期調查}

水温をみると，平均值は表層で $11.9^{\circ} \mathrm{C}$, 下層で $12.4^{\circ} \mathrm{C}$ と表層の方が下層よりも $0.5^{\circ} \mathrm{C}$ 低い．前期 と比べると両層とも平均で $5.4^{\circ} \mathrm{C}$ 低い. 塩分をみると平均は表層で $30.63 \%$, 下層で $31.14 \%$ と下層 の方が表層よりも $0.51 \%$ 高い. 前期と比べると両層とも塩分は高くなっている. 特に表層の塩分は 前期よりも $1.51 \%$ も高い。この期間，前期にみられたような塩分急変はない。しかし表層の塩分の 時間変化をみると, 塩分が一時的にその直前の值よりも $1 \%$ 以上急激に低下している部分が数力所 みられる。これらの部分では水温も $1^{\circ} \mathrm{C}$ から $2^{\circ} \mathrm{C}$ 程度直前の值よりも低下しており, この時期に表 層では低塩分で低温の水が存在していた様子がうかがえる.

\section{4. 解析結果と考察}

\section{1 スペクトル解析}

前期と後期の両層における塩分と水温の観測データよりBlackman-Turkey法を使ってスペクト ルを求めた ${ }^{2)}$. その結果を図 5 に示す。この図より前期の塩分では, 両層とも 1 日周期成分に最 も大きなピークがあり，ついで半日周期成分にもピークが認められる．前期の水温では，両層とも 

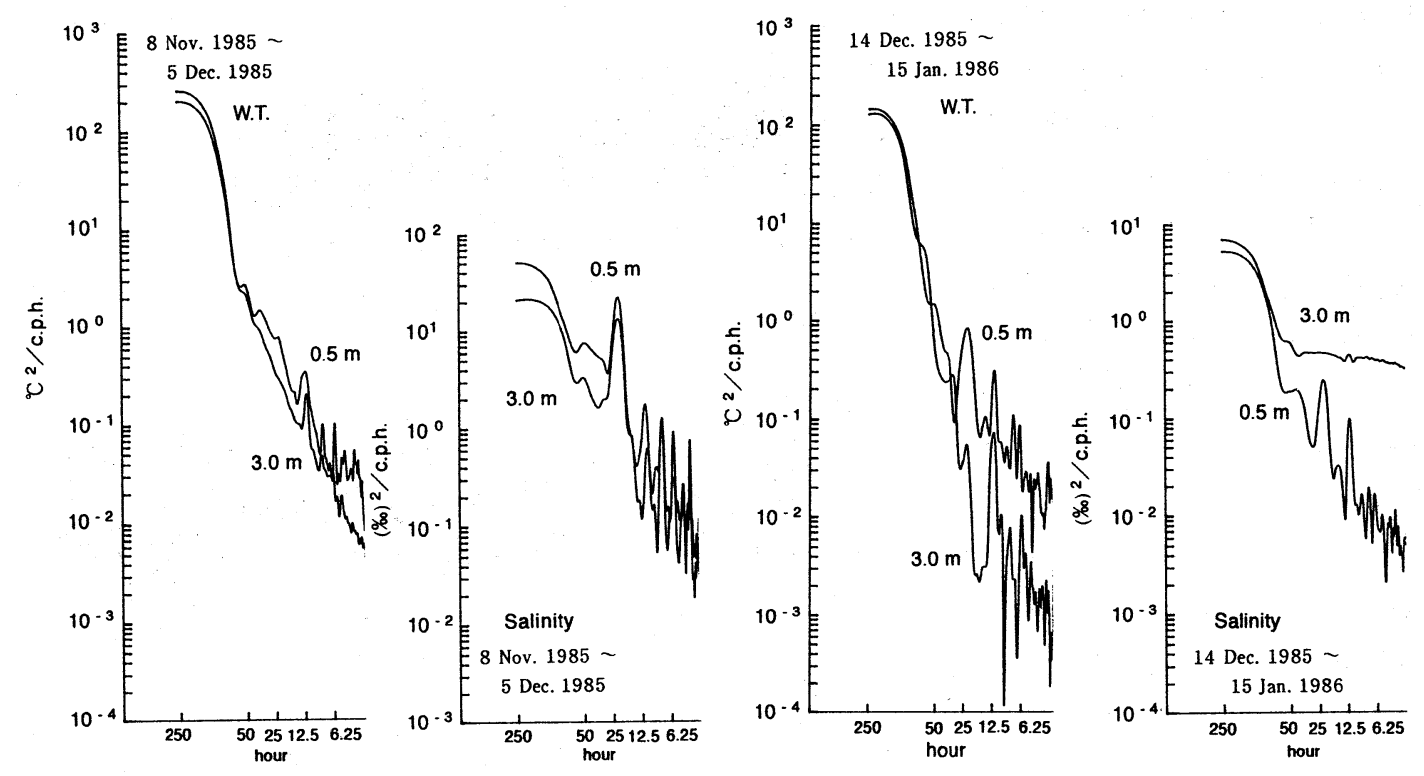

図－5＼cjkstart水温と塩分のパワースペクトル

半日成分に最も大きなピークがあり，1日成分には表層に僅かにピークが認められるが，下層には まったくない，後期の塩分では，表層では前期と同様に 1 日周期成分に最も大きなピークがあり， ついで半日周期成分にもピークが認められる。しかし，下層では半日周期成分に僅かなピークが認 められる以外にはピークはない，後期の水温では，表層をみると 1 日周期成分に最も大きなピーク があり，ついで半日周期成分にもピークが認めれる。一方，下層をみると半日周期成分に大きなピ 一クがあり，1日周期成分にも僅かなピークが認められる.

\section{2 調和分解}

水温・塩分の観測期間中の潮位データを1985年11月 23 日から 12月7日，12月 14 日から 28 日および1986年1月 1 日から 1 月 15 表 1 潮汐の調和分解 (振幅； c m) 日までの3期間（各15日間）に分けて調和分解を行なっ た。求めた各分潮のうち, 主太陰半日周潮 $\left(\mathrm{M}_{2}\right)$, 主太陽半日 周潮 $\left(\mathrm{S}_{2}\right)$ ，主太陰日周潮（O 1 ) および気象日周潮 $\left(\mathrm{S}_{1}\right)$ の 4 つの分潮の振幅を表 1 に記載した。 なお, 調和解析はフーリ 工級数による方法を用いた3）。この表から 4 分潮の中で各期間

\begin{tabular}{ccccc}
\hline & $\mathrm{O}_{1}$ & $\mathrm{~S}_{1}$ & $\mathrm{M}_{2}$ & $\mathrm{~S}_{2}$ \\
\hline $\begin{array}{c}11 \text { Nov. 1985 } \\
\sim 7 \text { Dec. }\end{array}$ & 10.97 & 12.04 & 14.35 & 6.67 \\
$\begin{array}{c}\text { 14 Dec. 1985 } \\
\sim \text { 28 Dec. }\end{array}$ & 11.75 & 14.41 & 15.06 & 5.18 \\
$\begin{array}{c}\text { 1 Jan. 1986 } \\
\text { 15 Jan. }\end{array}$ & 12.18 & 13.97 & 18.21 & 6.66 \\
\hline
\end{tabular}
とも $\mathrm{M}_{2}$ の振幅がもっとも大きく，ついで $\mathrm{S}_{1}$ の順となっている. また 3 期間で各分潮に大きな違いはみられない.

\section{3 流動の評価}

前述のように池内の塩分の変化パターンは外海潮位と密接に関連している. しかし，塩分の変化 パターンは池内の流況とより直接的に結びついているはずである．このことを検討するため，池の 流動, 特に各池を結ぶ水路の流量の変化を求め, これと塩分の変化パターンとの対応関係を調べる. 流量の評価は，前報4，5）の水収支モデルにより行なう．前報の水収支モデルを若干説明する．大 池と中の池の水位が低下する時間带では, 両池はいずれも外海や奥の池の水位よりも高くなってい る.したがって，この時間帯には大池，中の池の水は外海と奥の池の両方に流れ出しているはずで ある。一方，奥の池の水位は他の 2 池の水位よりも急激に低下しており，したがって，この時間帯 のうち奥の池の水位が下降から上昇に転ずるまでの間，相当な量の奥の池の水が周界に流出してい 
ることになる．一方，外海水が大池へ流入する時間帯では奥の池から中の池方向に水が流れる. 以上の水の動きを図-6のようにモデル化すると，池水位を規定する方程式は次式となる4）.

$$
S_{a} \frac{d Z_{a}}{d t}=Q_{e a}-Q_{a b} \ldots \ldots \ldots \ldots . . . .(1), \quad S_{b} \frac{d Z_{b}}{d t}=Q_{a b}-Q_{b s}
$$

ここで, $\mathrm{Z}_{\mathrm{a}}, \mathrm{Z}_{\mathrm{b}}$ は池 $\mathrm{A}$ (奥の池)， $\mathrm{B}$ (大池十中の池) の水位, $\mathrm{S}$ a と $\mathrm{S}$ bは各々池 $\mathrm{A}$ と Bの水 表面積, $\mathrm{Q}_{\mathrm{ea}}, \mathrm{Q}_{\mathrm{ab}}$ および $\mathrm{Qbs}$ は各々周界から池 $\mathrm{A} へ$, 池 $\mathrm{A}$ から池 $\mathrm{B} へ$, 池 $\mathrm{B}$ から外海への流量, $\mathrm{t}$ は時間である。 $\mathrm{Q} a b, \mathrm{Qbs}$ および $\mathrm{Q}_{\mathrm{ea}}$ は簡単のため次のようにおいた。

$$
\begin{gathered}
Q_{a b}=\frac{1}{n_{a b}} b_{a b}\left|\frac{Z_{a}+Z_{b}}{2}-Z_{h}\right|^{\frac{5}{3}}\left|\frac{Z_{a}-Z_{b}}{L_{a b}}\right|^{\frac{1}{2}} \operatorname{sgn}\left(Z_{a}-Z_{b}\right) \\
Q_{b s}=\frac{\pi}{4} D^{2}\left\{\frac{2 g\left|Z_{b}-Z_{s e a}\right|}{\zeta_{e}+\zeta_{0}+f \frac{L_{b s}}{D}}\right\}^{\frac{1}{2}} \operatorname{sgn}\left(Z_{b}-Z_{s e a}\right) \\
Q_{e a}=k b_{e a} h_{e a} \frac{Z_{e}-Z_{a}}{L_{e a}}
\end{gathered}
$$

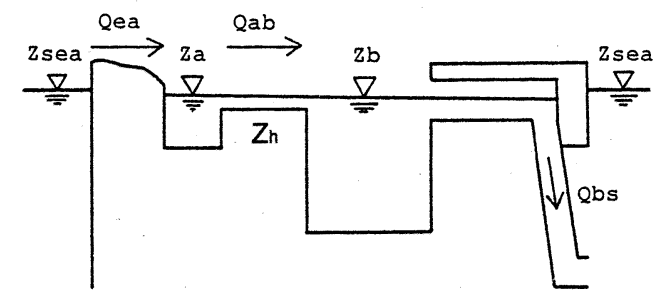

$$
\text { 図一－モデル池 }
$$

記号および諸量の諸元については前報に詳述されている.図- 7 は外海水位の測定值（1985年11月 11日から21日および11月23日から12月5日までの期間）と水収支式から得られた流量 Q bs，Qeaお よび $\mathrm{Q}_{\mathrm{ab}}$ の時間変化を示している．まず，急変期の起こる前一週間では $\mathrm{Q}_{\mathrm{ab}}$ の出入が相当量あった ことがわかる，次に急変期間では，低塩分の時期は $\mathrm{Q}_{\mathrm{ab}}$ の出入りのある時と一致しており，逆に高 塩分の時期は $\mathrm{Q}_{\mathrm{ab}}=0$ すなわち $\mathrm{B}$ 池と $\mathrm{A}$ 池の水の出入りの無い時期と一致している。ただし, 両層 が急変している時期から表層のみ急変期への移行期には $Q_{\mathrm{ab}}$ の出入りのある時期に表層の塩分が高 くなっている，Qbsとの関係をみると，両層が急変期の間は振幅の大きい間に低塩分となり，振幅 の小さい間に高塩分となっている，一方，表層のみ急変期には振幅の小さい間に低塩分となり，振 幅の大きい間に高塩分となり，上述と逆の傾向である．以上のことから，水の動きを考察すると次 のようになる. 池内水位の上昇期に奥の池より大池に流入した低塩分で低水温の水は，池内水位の 下降期に大池内にその一部が閉じ込められ，大池が干潮から満潮の間に測点の表層ではこの水が占 め，満潮から干潮の間にこの付近では高塩分の水が占める。さらに池内水位が上昇期にはこのパ夕 ーンは表層から下層まで拡大している，以上で考察した低塩分で低温の水の動きは前報で考察した 地下水の流動と一致する，なお，大池表層と下層では基本的に密度が異なっており，したがって物 質収支を考える際には大池内の成層を考慮する必要がある.

\section{4 密度}

水温と塩分より表層と下層の池水の密度を算出した6) 。その結果を図- 8 に示す。図をみると, 塩分の急変期に一時的に表層よりも下層の池水の密度が僅かながら小さくなっている。これは測点 付近の地形が浅瀬から急激に深くなっていることから，コアンダ効果7，8）の影響が考えられる. 
5.まとめ

池内で水温と塩分の連続測定を行ない，表層と 下層の塩分が約 1 日周期で急激に変化する期間の あることを見いだした。この現象の生じる機構に ついて検討した結果次のようなことがわかった。

1）塩分急変の起こる前の一週間の潮位は上昇期 （高高潮で $220 \mathrm{c} \mathrm{m}$ ）にあたり，表層のみ急変す る時期の潮位は逆に下降期（高高潮で $180 \mathrm{c} \mathrm{m}$ ) にあたる。また，塩分急変の生じない期間では， その期間の潮位は高高潮でもほとんど $200 \mathrm{c} \mathrm{m}$ 以 下である，2）各池間の流量算出結果より塩分急 変の起こる一週間前に奥の池と大池で相当量の水 の出入りがあった．塩分急変期では，低塩分の状 態にある時間帯に奥の池と大池とで水の出入りが あり，逆に高塩分の状態にある時間帯では両池で 水の出入りは無かった。謝辞：本研究の現地調 査にあたり，萩市教育委員会，（同）越ヶ浜漁業 協同組合の各位と宇部短期大学付属環境科学研究 所の諸氏に多大な助力を頂いた。また，国土地理 院に貴重な潮位デー夕を提供頂いた。さらに山口 大学工学部 4 年生の酒見正明君には資料整理に協 力頂いた。記して深甚の謝意を表す。

参考文 献

1）合屋・松本 ·城田：塩水池「明神 池」の富栄養化におよぼす地下水起 源の低塩分水塊の影響,宇部短大環科 研報告,4,1983．2）日野：スペクト 儿解析,朝倉書店,1983.3）松本：河 口と沿岸部における表層水温の周期 成分とその季節変化, 宇部短大報 告,26,1989.4）松本 ·羽田野 ·斎 藤：外海と連結された湖沼の水位変 動,水工学論文集,36,1992.5)松本. 合屋 · 羽田野 ・斎藤 : 明神池におけ る水塊の流動と物質濃度の変動, 土木 学会論文集,No.491/II-27,1994.

6）気象庁編：海洋観測指針,日本海洋学会,1985．7）玉井・有田：斜めに放流される表層密度噴流 の流軸の曲がりに関する研究,第29回海岸工学講演会論文集,1982. 8) . 有田・玉井：汀線に対して 斜めに放流される噴流の再付着現象に関する実験的研究,第29回水理講演会論文集,1985.
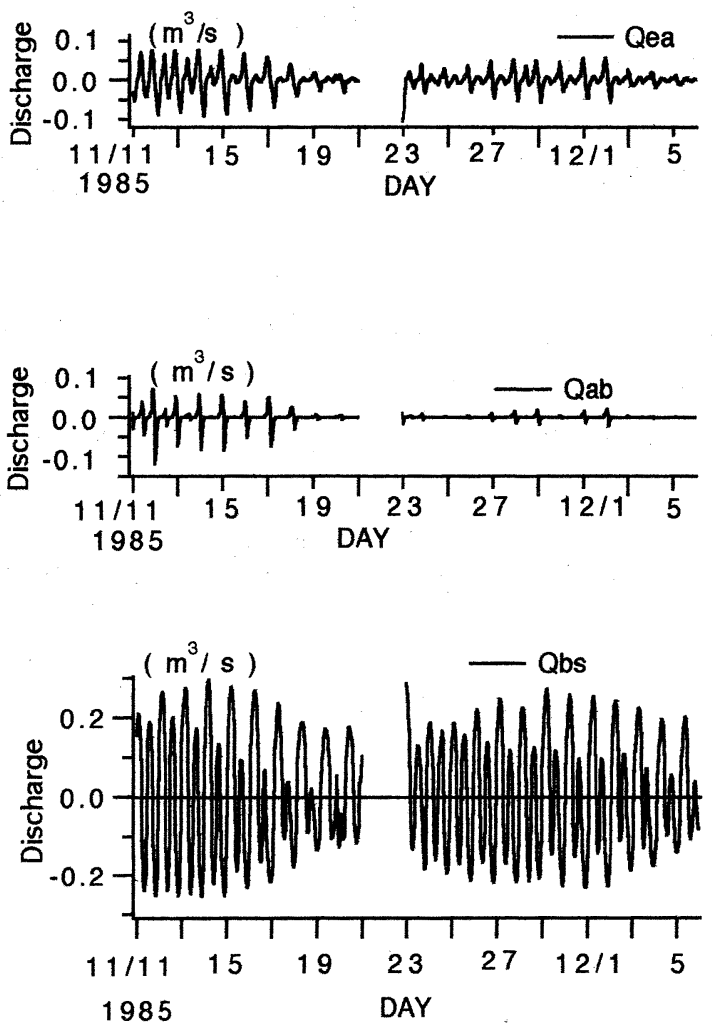

図 -7 流量の時間変化
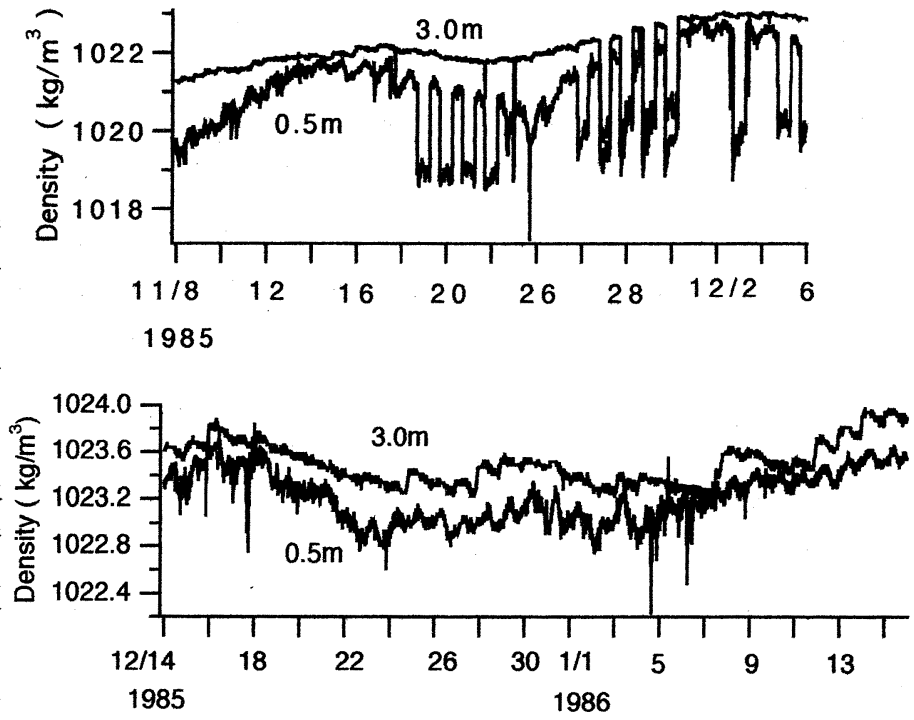

図 -8 密度の時間変化 